\title{
Molecular analysis of East Anatolian traditional plum and cherry accessions using SSR markers
}

\author{
M.H. Öz ${ }^{1}$, H. Vurgun ${ }^{1}$, M. Bakir ${ }^{2}$, İ. Büyük ${ }^{3}$, C. Yüksel ${ }^{2}$, H.M. Ünlü ${ }^{1}$, \\ K. Çukadar ${ }^{1}$, B. Karadoğan ${ }^{1}$, Ö. Köse ${ }^{3}$ and A. Ergül ${ }^{2}$ \\ ${ }^{1}$ Ministry of Food, Agriculture and Livestock, \\ General Directorate of Agricultural Research and Policy, \\ Horticultural Research Station, Erzincan, Turkey \\ ${ }^{2}$ Biotechnology Institute, Ankara University, Ankara, Turkey \\ ${ }^{3}$ Department of Biology, Faculty of Science, Ankara University, \\ Ankara, Turkey \\ Corresponding author: A. Ergül \\ E-mail: ergul@agri.ankara.edu.tr
}

Genet. Mol. Res. 12 (4): 5310-5320 (2013)

Received November 22, 2012

Accepted April 27, 2013

Published November 7, 2013

DOI http://dx.doi.org/10.4238/2013.November.7.6

\begin{abstract}
We conducted SSR analyses of 59 accessions, including 29 traditional plum (Prunus domestica), 24 sweet cherry (Prunus avium), and 1 sour cherry (Prunus cerasus) selected from East Anatolian gene sources and 3 plum and 2 cherry reference accessions for molecular characterization and investigation of genetic relationships. Eight SSR loci [1 developed from the apricot (UDAp-404), 4 from the peach (UDP96-010, UDP96-001, UDP96-019, Pchgms1) and 3 from the cherry (UCD-CH13, UCD-CH17, UCD-CH31) genome] for plum accessions and 9 SSR loci [5 developed from the cherry (PS12A02, UCD-CH13, UCD-CH17, UCD-CH31, UCD-CH21), 3 from the peach (Pchgms1, UDP96-001, UDP96-005) and 1 from the plum (CPSCT010) genome] for cherry accessions were used for genetic identification. A total of 66 and 65 alleles were obtained in the genetic analyses of 31
\end{abstract}


plum and 28 cherry accessions, respectively. The number of alleles revealed by SSR analysis ranged from 4 to 14 alleles per locus, with a mean value of 8.25 in plum accessions, and from 5 to 10 alleles per locus with a mean value of 7.2 in cherry accessions. Only one case of synonym was identified among the cherry accessions, while no case of synonym was observed among the plum accessions. Genomic SSR markers used in discrimination of plum and cherry accessions showed high cross-species transferability in the Prunus genus. Because of their appreciable polymorphism and cross species transferability, the SSR markers that we evaluated in this study will be useful for studies involving fingerprinting of cherry and plum cultivars.

Key words: East Anatolia; Plum; Cherry; Genetic diversity; SSR

\section{INTRODUCTION}

Rosaceae, which involves the fruits (apples, strawberries), forest (mazzard) and ornamental (rose) species, is the third most agronomically important plant family in temperate regions. Cherry and the plum are two species belonging to the Prunus genus (Rosaceae), which is a large and diverse genus, comprising about 400 species of trees and shrubs, including other economically important species (apricot, almond, plum, and cherry) (Dirlewanger et al., 2002). The wild and cultivated forms of cherries and plums, in Turkey show a relatively large diversity due to their good adaptation to various ecogeographical conditions within the Anatolian region (Onur, 1977; Özakman et al., 1993; Ayanoğlu, 1995).

Plums (Prunus domestica L.) are cultivated plants that are mostly classified into three groups, namely European, American, and Asian plums, and are economically important since only some of these species display desirable quality traits (Salesses et al., 1994). Anatolia, which is the Asian part of Turkey, has played a significant role in the sustaining and conserving the cultivated plum types to date (Asma, 2000). With a production figure of 143,705 tonnes, Turkey is the eighth largest producting country in the world after China, USA, Serbia, Romania, Chile, France and Iran (FAOSTAT, 2008). In the coastal areas and in Central, South and East Anatolia, plums are grown for use as table, early grown, deep-frozen and canned forms (Gülcan et al., 2000).

Cherry (Prunus avium L.) is an economically viable fruit originating from around the Caspian and Black Sea, as well as Northeast Anatolia, which then spread throughout the world. The distinctiveness among the cherry accessions in breeding and cultivation is fairly important for scientific as well as economic reasons (Struss et al., 2003; Ganopoulos et al., 2011). Cherry production is carried out in the Central Anatolia and Marmara regions, which are suitable regions due to the long harvest time and abundant sunshine (Asma, 2000). Like other species, cherry also has a great genetic diversity potential in Anatolia. Turkey is the leading country in world exportation with a production figure of 531,270 tonnes (FAOSTAT, 2008).

The analysis of genetic diversity of accessions has traditionally been based on morphological traits, although DNA markers do allow for a more precise identification of plant genotypes. Different molecular techniques such as amplified fragment length polymorphism and simple sequence repeats (SSR) have been developed for measuring genetic variability, and 
several studies have been performed on the identification of cherry and plum genotypes using molecular markers (Granger et al., 1993; Gerlach and Stösser, 1998; Wünsch and Hormaza, 2002; Struss et al., 2003; Ayanoğlu et al., 2007; Mariette et al., 2010).

The objectives of this study were the molecular characterization and establishment of genetic relationships between traditional Turkish cultivated plum and cherry accessions collected from diverse geographical regions in East Anatolia, together with the novelty of the use of SSR markers in the identification of field samples. The data from this study provide a valuable reference for the genetic base of breeding programs and contribute to an international genetic database.

\section{MATERIAL AND METHODS}

\section{Plant material and DNA isolation}

A total of 59 accessions, namely 29 traditional and 2 reference plum (Prunus domestica L.) and 25 traditional [24 sweet cherry (Prunus avium L.) and 1 sour cherry (Prunus cerasus L.)] and 3 reference cherry (Prunus avium L.) accessions, were analyzed in this study. These cultivated plum and cherry accessions were selected from East Anatolia and maintained at the "Horticultural Research Station/Erzincan". The names of the plum and cherry accessions and the collection sites are presented in Tables 1 and 2, respectively.

Table 1. Accession code, collection sites, allele sizes (bp) of selected traditional plum and accessions at 8 SSR loci.

\begin{tabular}{|c|c|c|c|c|c|c|c|c|c|c|c|c|c|c|c|c|c|c|}
\hline \multirow{2}{*}{$\begin{array}{c}\text { No. } \\
1\end{array}$} & \multirow{2}{*}{$\begin{array}{l}\begin{array}{l}\text { Accession } \\
\text { code }\end{array} \\
24 \text { plu001 }\end{array}$} & \multirow{2}{*}{$\begin{array}{l}\text { Collection } \\
\text { site (City) }\end{array}$} & \multicolumn{2}{|c|}{ UDAp-404 } & \multicolumn{2}{|c|}{ UDP96-010 } & \multicolumn{2}{|c|}{ UDP96-001 } & \multicolumn{2}{|c|}{ UDP96-019 } & \multicolumn{2}{|c|}{ Pchgms 1} & \multicolumn{2}{|c|}{ UCD-CH13 } & \multicolumn{2}{|c|}{ UCD-CH17 } & \multicolumn{2}{|c|}{ UCD-CH31 } \\
\hline & & & 161 & 167 & 87 & 87 & 97 & & 168 & 168 & 166 & 174 & 128 & & 146 & & 164 & 164 \\
\hline 2 & 24plu002 & Iğdır & 169 & & 75 & 75 & 101 & & & 17 & & & & & & & & 164 \\
\hline 3 & 24plu003 & imïs & 163 & 16 & & & & & & 170 & 164 & & & & & & & 164 \\
\hline 4 & 24plu004 & & 167 & 16 & & & & & & & 164 & & & 134 & & & & 164 \\
\hline 5 & & & 163 & 16 & 63 & & 95 & & & 170 & 164 & & & 132 & & & & 166 \\
\hline 6 & & & 155 & 16 & 63 & 97 & 95 & 95 & & 17 & 174 & & & 132 & & & & 170 \\
\hline 7 & & & 161 & 177 & 75 & 87 & 97 & 101 & 16 & 17 & 168 & 174 & 12 & 132 & & & & 170 \\
\hline 8 & & & 159 & 15 & 75 & 87 & 95 & & & 17 & 176 & & & 132 & & & & 170 \\
\hline 9 & & & 171 & 17 & 97 & 97 & 97 & & & 17 & 174 & & & & & & & 170 \\
\hline 10 & & & & 17 & 75 & 99 & 97 & & & 17 & & & & & 15 & & & 170 \\
\hline 11 & & & & 17 & 7 & 89 & & & & & & & & & & & & 170 \\
\hline 12 & & & & 16 & 6 & 8 & & & & & & & & & & & & 164 \\
\hline 13 & & & & 17 & 63 & 87 & & & & 17 & & & & & 12 & & & 170 \\
\hline 14 & & & & 17 & 7 & & & & & 1 & & & & & & & & 164 \\
\hline 15 & & & & & & & & & & & & & & & & & & 170 \\
\hline 16 & & & & & & & & & & & & & & & & & & 166 \\
\hline 17 & & & & & & 7 & & & & & & & & & & & & 166 \\
\hline 18 & & & 155 & 16 & 8 & 101 & & & & & & & & & 12 & & & 170 \\
\hline 19 & & & 163 & 171 & 7 & 75 & 101 & & & & 172 & & & 136 & 16 & & & 166 \\
\hline 20 & & & 161 & 167 & 75 & 87 & 99 & & & 170 & 164 & & 128 & 132 & 13 & & & 166 \\
\hline 21 & & & 167 & 173 & 75 & 75 & 97 & 11 & 166 & 172 & 166 & 174 & 128 & 132 & 13 & 150 & & 164 \\
\hline 22 & & & 161 & 161 & 71 & 71 & 103 & & & 168 & 164 & & 128 & 136 & 13 & 160 & & 166 \\
\hline 23 & & & & & 91 & 91 & & & & & 164 & & 128 & & 14 & & & 164 \\
\hline 24 & & & 159 & & 7 & 91 & & & & & & & & & & & & 164 \\
\hline 25 & & & 17 & 17 & 6 & 9 & & & & & & & & 13 & & & & 166 \\
\hline 26 & & & & 16 & 7 & & & & & & & & & & & & & 170 \\
\hline 27 & & & 17 & 17 & 63 & 93 & 10 & & & & & & & 13 & & & & 164 \\
\hline 28 & & & 16 & 17 & 75 & 101 & 9 & 10 & 17 & 17 & 16 & 18 & 1 & 132 & 15 & & & 170 \\
\hline 29 & & & & 17 & 75 & 93 & & 10 & & 17 & & & 12 & 13 & & & & 170 \\
\hline 30 & & & & 171 & 91 & 91 & & 10 & 16 & 170 & & & 128 & 132 & & & & 170 \\
\hline 31 & Obilnaja & Japan & 171 & 171 & 75 & 75 & 99 & 99 & 168 & 168 & 170 & 174 & 128 & 136 & 136 & 186 & 150 & 164 \\
\hline
\end{tabular}


Table 2. Accession code, collection sites, allele sizes (bp) of selected traditional cherry accessions at 9 SSR loci.

\begin{tabular}{|c|c|c|c|c|c|c|c|c|c|c|c|c|c|c|c|c|c|c|c|c|}
\hline \multirow{2}{*}{$\begin{array}{l}\text { No. } \\
1\end{array}$} & \multirow{2}{*}{$\begin{array}{l}\begin{array}{l}\text { Accession } \\
\text { code }\end{array} \\
24 \text { che } 001\end{array}$} & \multirow{2}{*}{$\begin{array}{l}\begin{array}{l}\text { Collection } \\
\text { site (City) }\end{array} \\
\text { Erzurum }\end{array}$} & \multicolumn{2}{|c|}{ PS12A02 } & \multicolumn{2}{|c|}{ UCD-CH13 } & \multicolumn{2}{|c|}{ UCD-CH17 } & \multicolumn{2}{|c|}{ UCD-CH31 } & \multicolumn{2}{|c|}{ UCD-CH21 } & \multicolumn{2}{|c|}{ Pchgms1 } & \multicolumn{2}{|c|}{ UDP96-001 } & \multicolumn{2}{|c|}{ UDP96-005 } & \multicolumn{2}{|c|}{ СРSCT 010} \\
\hline & & & 160 & 160 & 136 & 136 & 198 & 206 & 130 & 130 & 109 & 109 & 138 & 138 & 97 & 109 & 119 & 133 & 178 & 180 \\
\hline 2 & 24che002 & Van & 160 & 160 & 128 & 136 & 188 & 198 & 130 & 134 & 109 & 109 & 130 & 138 & 105 & 109 & 119 & 135 & 176 & 176 \\
\hline 3 & 24 che 003 & Erzurum & 158 & 166 & 128 & 136 & 186 & 186 & 130 & 130 & 109 & 119 & 130 & & 109 & 109 & 115 & 135 & 178 & 178 \\
\hline 4 & 24 che 004 & Erzurum & 152 & 152 & 128 & 136 & 202 & 202 & 134 & 140 & 107 & 111 & 140 & 184 & 109 & 123 & 135 & 135 & 178 & 178 \\
\hline 5 & 24 che 005 & Van & 158 & 158 & 128 & 136 & 202 & 202 & 134 & 142 & 107 & 111 & 140 & 184 & 109 & 123 & 135 & 135 & & 178 \\
\hline 6 & 24 che 006 & Erzurum & 166 & 166 & 128 & 136 & 198 & 198 & 134 & 134 & 111 & 119 & 130 & 138 & 109 & 109 & 119 & 135 & 178 & 182 \\
\hline 7 & 4 che 00 & Van & 150 & 166 & 122 & 136 & 198 & 198 & 134 & 134 & 111 & 119 & 130 & 138 & 109 & 109 & 119 & 135 & 17 & 182 \\
\hline 8 & 4che008 & Va & 150 & 160 & 12 & 136 & 198 & 198 & 130 & 13 & 109 & 109 & 138 & 138 & 109 & 12 & 119 & 133 & 17 & 176 \\
\hline 9 & 24 che 0 & curum & 160 & 160 & 128 & 136 & 198 & 198 & 132 & 13 & 10 & 119 & 138 & 138 & 101 & 125 & 123 & 135 & 176 & 176 \\
\hline 10 & 4che 0 & $\mathrm{E}$ & 160 & 160 & 128 & 136 & 19 & 204 & 130 & 13 & 11 & 111 & 138 & & 101 & 12 & 119 & 119 & & 178 \\
\hline 11 & 4che 0 & Van & 164 & 164 & 128 & 136 & 192 & 198 & 122 & 134 & $10 \mathrm{~s}$ & 109 & 130 & 138 & 115 & 123 & 115 & 119 & 176 & 176 \\
\hline 12 & 24che 012 & Van & 160 & 166 & 128 & 136 & 188 & 204 & 130 & 130 & 10 & 119 & 130 & 130 & 109 & 123 & 109 & 133 & 178 & 178 \\
\hline 13 & 24che013 & Erzurum & 158 & 158 & 128 & 136 & 188 & 200 & 130 & 134 & & 111 & 136 & 156 & 123 & 123 & 119 & 123 & 178 & 178 \\
\hline 14 & 2 & & 1 & 15 & 12 & 136 & 19 & 202 & 14 & 14 & & 119 & 1 & 13 & 109 & 12 & 119 & 135 & 178 & 182 \\
\hline 15 & 24 che 015 & Gümüşhane & 158 & 158 & 122 & 136 & 188 & 200 & 130 & 13 & 111 & 111 & 136 & 152 & 123 & 123 & 119 & 119 & 178 & 178 \\
\hline 16 & 24 che 016 & Artvin & 158 & 158 & 126 & 136 & 190 & 202 & 142 & 142 & 109 & 119 & 138 & 138 & 109 & 123 & 119 & 135 & 178 & 182 \\
\hline 17 & & & 162 & 16 & 12 & 13 & & 19 & & 13 & & 109 & & & 115 & & 11 & & & 176 \\
\hline 18 & 4che018 & A & 160 & 160 & 128 & 136 & 198 & 206 & 122 & 13 & 11 & 111 & 130 & 13 & 105 & 123 & 119 & 135 & 176 & 176 \\
\hline 19 & 24 che 019 & E & 158 & 166 & 12 & 136 & 18 & 20 & 130 & 13 & 109 & 109 & 13 & 138 & 109 & 109 & 109 & 133 & 178 & 178 \\
\hline 20 & & & 164 & 17 & 13 & 136 & 19 & 21 & 12 & 12 & & 11 & 13 & 138 & 123 & 12 & 119 & & 1 & 176 \\
\hline 21 & $\mathrm{~K}$ & & 158 & 15 & 13 & 13 & 19 & 20 & 14 & 14 & 10 & 11 & & 13 & 109 & 12 & 119 & & & \\
\hline 22 & K-M & $\mathrm{U}$ & 162 & 180 & 136 & 136 & 200 & 200 & 124 & 130 & 111 & 11 & 13 & 140 & 105 & 125 & 119 & 135 & 176 & 176 \\
\hline 23 & K-SF & nkno & 164 & 176 & 13 & 136 & 19 & 214 & 124 & 124 & 10 & 11 & 138 & 138 & 123 & 123 & 119 & 135 & 176 & 176 \\
\hline 24 & & & 158 & 164 & 12 & 13 & & 20 & & 13 & & 10 & & & 97 & & & & & \\
\hline 25 & Erz-Macar & Erzincan & 158 & 158 & 136 & 136 & 190 & 202 & 142 & 142 & 109 & 119 & 138 & 138 & 109 & 123 & 119 & 135 & 178 & 182 \\
\hline 26 & Lapins & Canada & 174 & 174 & 126 & 132 & 192 & 214 & 120 & 138 & 117 & 117 & 140 & 184 & 123 & 123 & 119 & 135 & 178 & 178 \\
\hline 27 & Bing & & 162 & 162 & 128 & 136 & 19 & 190 & 120 & 120 & 10 & 10 & 14 & 184 & 125 & 125 & 119 & 135 & 178 & 178 \\
\hline 28 & Rainer & USA & 160 & 176 & 128 & 136 & 188 & 202 & 120 & 128 & 109 & 109 & 130 & 138 & 123 & 123 & 115 & 135 & 178 & 178 \\
\hline
\end{tabular}

DNA was extracted from young leaf tissue following the procedure described by Lefort et al. (1998). About $100 \mathrm{mg}$ young leaves were ground into a fine powder in liquid nitrogen and homogenized. The powder was transferred to a new $1.5-\mathrm{mL}$ polypropylene tube, and $1 \mathrm{~mL}$ DNA extraction buffer [50 mM Tris-HCl, pH 8.0, $20 \mathrm{mM}$ EDTA, pH 8.0, $0.7 \mathrm{mM}$ $\mathrm{NaCl}, 1 \%(\mathrm{w} / \mathrm{v})$ CTAB (hexadecyltrimethylammonium bromide), 2\% (w/v) PVP 40$]$ and $10 \mu \mathrm{L} 2$-mercaptoethanol ( $1 \%$ final concentration) were added. The mixture was vortexed for $5 \mathrm{~s}$ and then incubated for $15 \mathrm{~min}$ at $65^{\circ} \mathrm{C}$ in a water-bath. After incubation, an equal volume of chloroform/isoamyl alcohol (24:1) was added and the phases were separated by centrifugation at $16,000 \mathrm{~g}$ for $10 \mathrm{~min}$. The aqueous layer was collected and 0.54 volume of cold isopropanol $\left(-20^{\circ} \mathrm{C}\right)$ added to precipitate the DNA. The pellet was obtained after centrifugation at $16,000 \mathrm{~g}$ for $10 \mathrm{~min}$ and resuspended in $100 \mu \mathrm{L}$ TE $(10 \mathrm{mM}$ Tris- $\mathrm{HCl}, \mathrm{pH} 8.0$, $1 \mathrm{mM}$ EDTA) containing $15 \mu \mathrm{g} / \mathrm{mL}$ RNAse A and incubated for $30 \mathrm{~min}$ at $37^{\circ} \mathrm{C}$. Proteins were removed by adding $50 \mu \mathrm{L} 7.5 \mathrm{M}$ ammonium acetate, followed by centrifugation at $16,000 \mathrm{~g}$ for $10 \mathrm{~min}$. DNA in the supernatant was precipitated with a 0.54 volume of cold isopropanol; the pellet was dried at room temperature, resuspended in $100 \mu \mathrm{L} \mathrm{TE}$ and stored at $4{ }^{\circ} \mathrm{C}$. The DNA concentration was estimated spectrophotometrically and DNA quality was checked by agarose gel electrophoresis.

\section{SSR analysis}

A total of 8 SSR loci, namely 1 developed from apricot (UDAp-404), 4 from peach (UDP96-010, UDP96-001, UDP96-019, Pchgms1) and 3 from cherry (UCD-CH13, UCD-CH17, UCD-CH31), were used in the study for the genetic characterization of the plum accessions (Cipriani et al., 1999; Sosinski et al., 2000; Struss et al., 2003; Messina et 
al., 2004). For the genetic characterization of cherry accessions, a total of 9 SSR loci were used: 5 developed from cherry (PS12A02, UCD-CH13, UCD-CH17, UCD-CH31, UCDCH21), 3 from peach (Pchgms1, UDP96-001, UDP96-005) and 1 from plum (CPSCT010) (Cipriani et al., 1999; Sosinski et al., 2000; Struss et al., 2003; Messina et al., 2004; Mnejja et al., 2005). Polymerase chain reactions (PCR) and SSR analysis were performed as previously described by Şelli et al. (2007). PCR amplifications were performed in a 10- $\mu \mathrm{L}$ reaction mixture containing $15 \mathrm{ng}$ DNA, 5 pmol of each primer, $0.5 \mathrm{mM}$ dNTPs, $0.5 \mathrm{U}$ GoTaq DNA polymerase (Promega, Madison, WI, USA), and $1.5 \mathrm{mM} \mathrm{MgCl}$. The forward primers of each pair were labeled with WellRED fluorescent dyes D2 (black), D3 (green) and D4 (blue) (Proligo, Paris, France). The PCR conditions consisted of an initial cycle of $3 \mathrm{~min}$ at $94^{\circ} \mathrm{C}$, followed by 35 cycles of $1 \mathrm{~min}$ at $94^{\circ} \mathrm{C}, 1 \mathrm{~min}$ at $55-60^{\circ} \mathrm{C}$ and $2 \mathrm{~min}$ at $72^{\circ} \mathrm{C}$, with a final extension at $72^{\circ} \mathrm{C}$ for $10 \mathrm{~min}$. The PCR products were diluted with SLS (sample loading solution), followed by the addition of the Genomelab DNA Standard kit400 and electrophoresed in the CEQ 8800XL capillary DNA analysis system (Beckman Coulter, Fullerton, CA, USA). The allele sizes were determined for each SSR locus using the Beckman CEQ fragment analysis software. The analyses were repeated at least twice to ensure the reproducibility of the results.

\section{Genetic analysis}

Number of alleles $\left(N_{\mathrm{A}}\right)$, allele frequency, expected $\left(H_{\mathrm{E}}\right)$ and observed heterozygosity $\left(H_{\mathrm{O}}\right)$, estimated frequency of null alleles $(\mathrm{r})$, and probability of identity $(\mathrm{PI})$ were calculated for each locus using the "IDENTITY" 1.0 program (Wagner and Sefc, 1999) according to Paetkau et al. (1995). The "IDENTITY" software was also used to detect identical genotypes. Proportion of shared alleles was calculated by using ps [option 1-(ps)] as described by Bowcock et al. (1994) as genetic dissimilarity in the Microsat (version 1.5) program (Minch et al., 1995). These data were then converted to a similarity matrix and a dendrogram was constructed with UPGMA (unweighted pair-group method with arithmetic mean) (Sneath and Sokal, 1973), using the software NTSYS-pc (Numerical Taxonomy and Multiware Analysis System) (version 2.0) (Rohlf, 1988).

\section{RESULTS}

A total of 59 accessions, namely 29 traditional and 2 reference (Stanley, Obilnaja) plum (Prunus domestica L.) and 25 traditional and 3 reference (Lapins, Bings and Rainer) sweet cherry (Prunus avium L.) and sour cherry (Prunus cerasus L.) accessions originating from different geographical regions (Erzurum, Van, Gümüşhane, Artvin and Iğdır provinces) of East Anatolia were screened.

Sixty-six alleles were identified in the genetic analyses of 31 plum accessions and the allele sizes are displayed in Table 1. As far as the probability of identity (PI) is concerned, while UDAp-404 (11 alleles, PI: 0.041) locus was the most informative locus, UCD-CH13 locus (4 alleles, PI: 0.364) was identified as the least informative locus (Table 3$). H_{\mathrm{O}}$ ranged from 0.419 (UCD-CH31) to 0.967 (UCD-CH13) and $H_{\mathrm{E}}$ ranged from 0.607 (UCD-CH13) to 0.891 (UDAp-404). Mean $H_{\mathrm{O}}$ and $H_{\mathrm{E}}$ were 0.693 and 0.749 , respectively. The PI values ranged from 0.041 (UDAp-404) to 0.364 (UCD-CH13) (Table 3). 
Table 3. SSR loci, number of alleles $\left(N_{\mathrm{A}}\right)$, expected heterozygosity $\left(H_{\mathrm{E}}\right)$, observed heterozygosity $\left(H_{\mathrm{O}}\right)$, probability (PI), and the frequency of null alleles (r) of 31 plum and 28 cherry accessions.

\begin{tabular}{|c|c|c|c|c|c|c|c|c|c|c|c|}
\hline \multicolumn{6}{|c|}{ Plum accessions } & \multicolumn{6}{|c|}{ Cherry accessions } \\
\hline SSR Loci & $N_{\mathrm{A}}$ & $H_{\mathrm{E}}$ & $H_{\mathrm{O}}$ & PI & $\mathrm{r}$ & SSR Loci & $N_{\mathrm{A}}$ & $H_{\mathrm{E}}$ & $H_{\mathrm{O}}$ & PI & $\mathrm{r}$ \\
\hline UDAp-404 & 11 & 0.891 & 0.516 & 0.041 & 0.198 & PS12A02 & 10 & 0.819 & 0.357 & 0.095 & 0.254 \\
\hline UDP96-010 & 14 & 0.829 & 0.548 & 0.067 & 0.689 & UCD-CH13 & 5 & 0.594 & 0.857 & 0.350 & -0.164 \\
\hline UDP96-001 & 9 & 0.795 & 0.774 & 0.116 & 0.011 & UCD-CH17 & 10 & 0.865 & 0.678 & 0.059 & 0.100 \\
\hline UDP96-019 & 6 & 0.755 & 0.548 & 0.186 & 0.117 & UCD-CH31 & 10 & 0.832 & 0.5 & 0.086 & 0.181 \\
\hline Pchgms1 & 8 & 0.754 & 0.806 & 0.168 & -0.029 & $\mathrm{UCD}-\mathrm{CH} 21$ & 5 & 0.700 & 0.5 & 0.226 & 0.117 \\
\hline $\mathrm{UCD}-\mathrm{CH} 13$ & 4 & 0.607 & 0.967 & 0.364 & -0.224 & Pchgms1 & 7 & 0.673 & 0.571 & 0.205 & 0.06 \\
\hline UCD-CH17 & 10 & 0.866 & 0.709 & 0.062 & 0.083 & UDP96-001 & 7 & 0.698 & 0.607 & 0.230 & 0.053 \\
\hline \multirow[t]{2}{*}{ UCD-CH31 } & 4 & 0.632 & 0.419 & 0.332 & 0.130 & UDP96-005 & 6 & 0.689 & 0.857 & 0.254 & -0.099 \\
\hline & & & & & & CPSCT010 & 5 & 0.612 & 0.285 & 0.362 & 0.202 \\
\hline Total & 66 & 6.129 & 5.287 & & & Total & 65 & 6.469 & 5.212 & & \\
\hline Mean & 8.25 & 0.76 & 0.66 & & & Mean & 7.2 & 0.718 & 0.579 & & \\
\hline
\end{tabular}

The dendrogram generated from UPGMA cluster analysis of 31 plum accessions based on the Jaccard coefficient of genetic similarity revealed two main groups (Figure 1). Both groups were further divided into two major subgroups containing all of the plum accessions analyzed. No complete ecogeographical clustering was observed within these subgroups. The highest genetic similarity (95\%) was observed between accessions 7 (24plu007) and 10 (24plu010). Subsequently, a similarity of $76 \%$ was observed between accession 29 (24plu030) and accessions 7 and 10 (24plu007 and 24plu010). Apart from the aforementioned similarities, the plum accessions showed less than $70 \%$ similarity with each other. Stanley and Obilnaja which were used as the reference cultivars, were slightly distant from the traditional plum accessions in the dendogram constructed with SSR data.

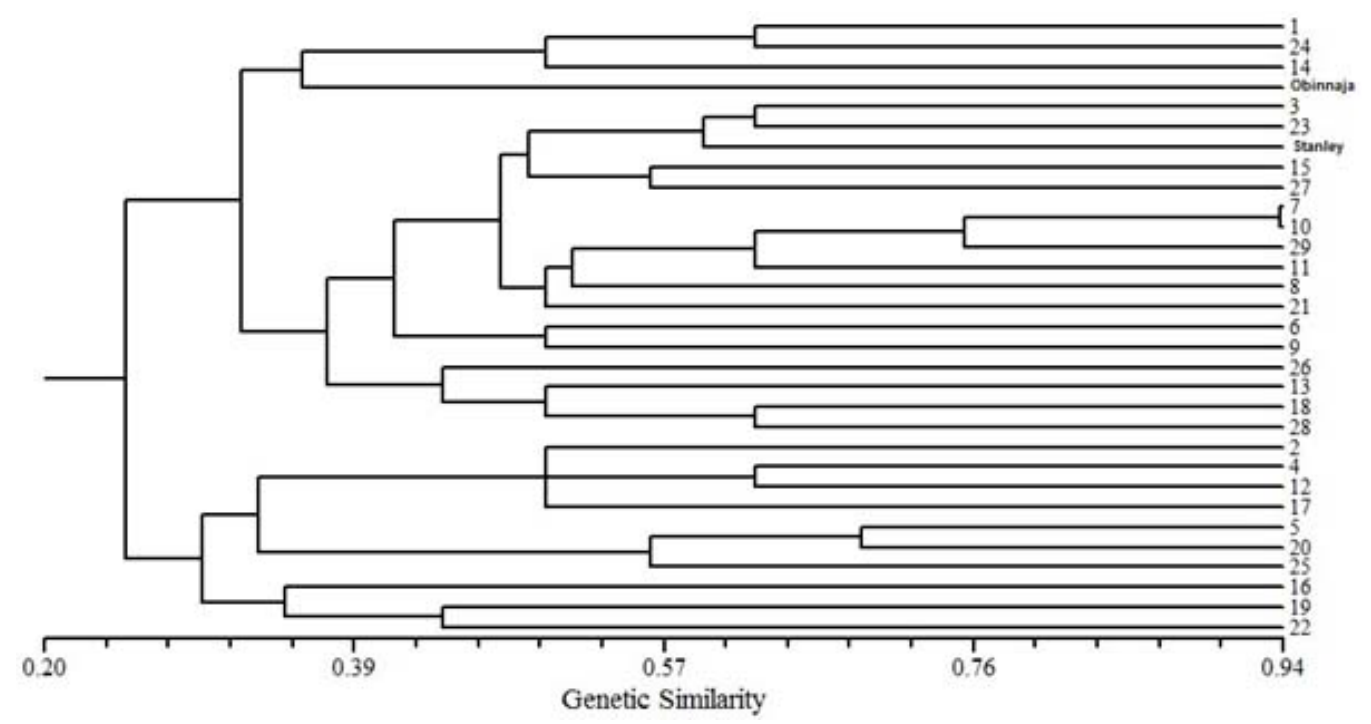

Figure 1. UPGMA Cluster analysis of the SSR data from plum accessions based on Jaccard's coefficient of genetic similarity. 
A total of 65 alleles were obtained in the genetic analyses of 28 cherry accessions, and the specific allele sizes revealed by these primers are presented in Table 2. With regard to the probability of identity (PI), while UCD-CH17 (10 alleles, PI: 0.059) locus was the most informative locus, CPSCT010 locus (5 alleles, PI: 0.362) was identified as being the least informative. $H_{\mathrm{O}}$ ranged from 0.285 (CPSCT010) to 0.857 (UCD-CH13, UDP96-005), and $H_{\mathrm{E}}$ ranged from 0.594 (UCD-CH13) to 0.865 (UCD-CH17). Mean $H_{\mathrm{O}}$ and $H_{\mathrm{E}}$ were 0.571 and 0.729 , respectively. The PI values ranged from 0.059 to 0.36 (Table 3 ).

The dendrogram generated from the UPGMA cluster analysis based on the Jaccard coefficient of genetic similarity classified all 28 cherry ( 27 sweet chery and 1 sour cherry) accessions included in this study into two main groups, which are depicted in Figure 2. In terms of genetic similarities between the accessions, the highest genetic similarity (94\%) was observed between the cherry accessions 16 (24che016) and 25 (Erzincan Macar), excepting the synonymous accessions. At the same time, these accessions could probably be considered as clonal mutants, showing one or 2 allele differences. There was $89 \%$ similarity identified between accessions 11 (24che011) and 17 (24che017), as well as between accessions 6 (24che006) and 7 (24che007). There was 83\% similarity identified between accessions 21 (K-ZIR), 16 (24che016) and 25 (Erz-Macar) and between accessions 13-15 and 4-5. Accessions 20 (K-ST) and 23 (K-SF) were identified as being synonymous. Apart from the above mentioned similarities, the cherry accessions showed less than $80 \%$ similarity with each other. The similarity between the sour cherry accession (Vişne 1) and sweet cherry accessions ranged from 11 to 39\%. The sour cherry accession 24 (Vişne1) and accession 22 (K-M1) formed a separate group and displayed a distinct branching pattern.

A dendrogram was generated on the basis of the selected common SSR loci (Pchgms1, UCD-CH13, UCD-CH17, UCD-CH31, UDP96-001) of the plum and cherry accessions. As indicated by the dendrogram, plum and cherry accessions were clustered in separate groups (Figure 3).

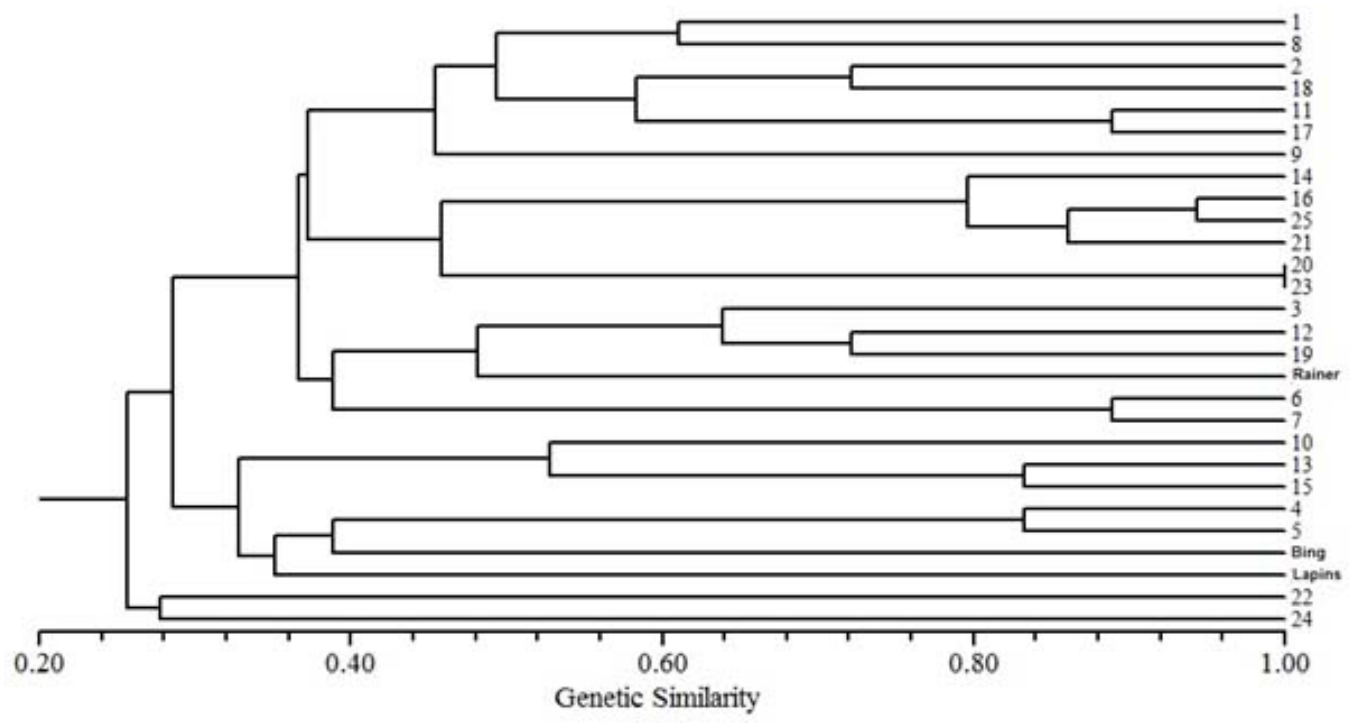

Figure 2. UPGMA Cluster analysis of the SSR data from cherry accessions based on Jaccard's coefficient of genetic similarity. 


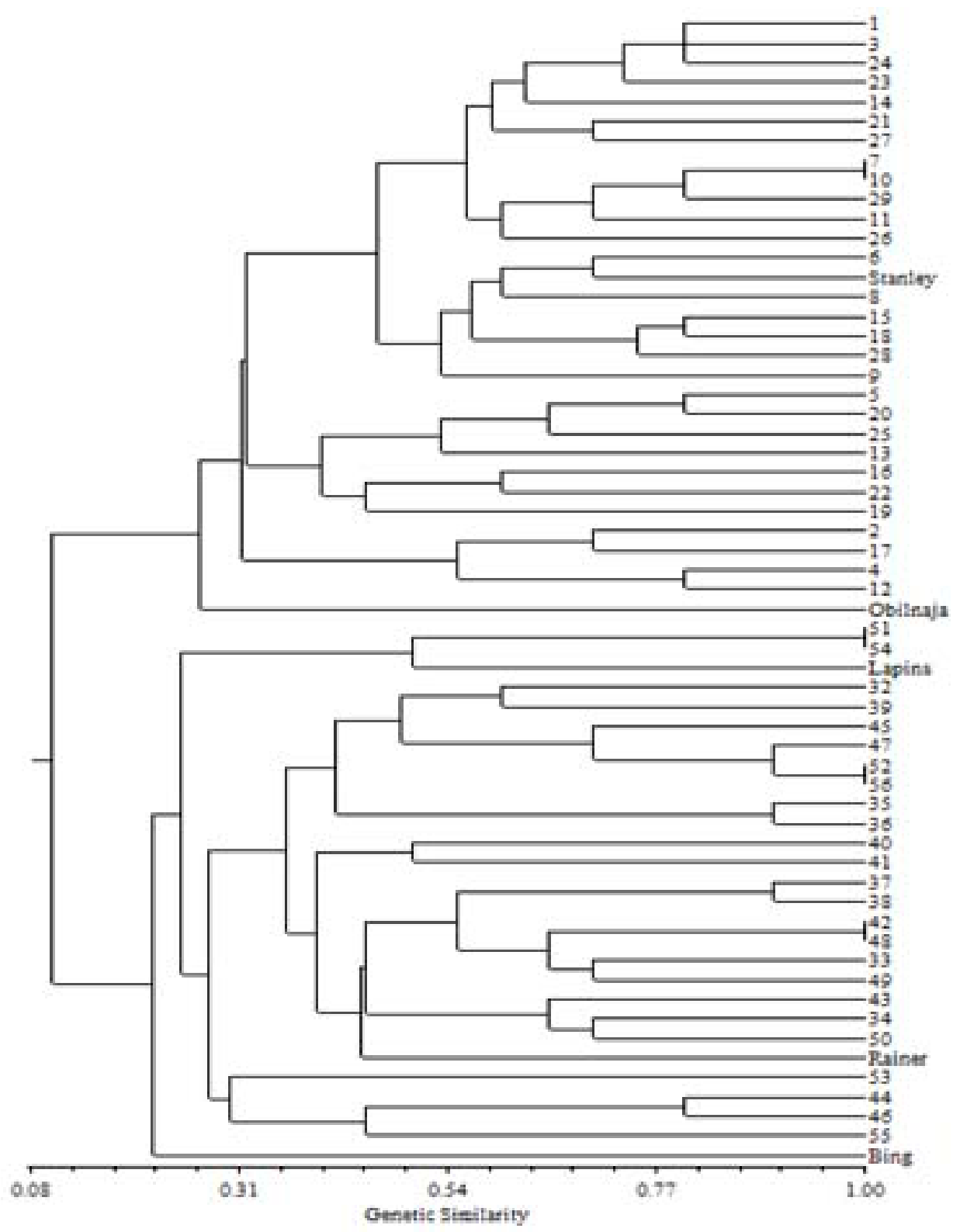

Figure 3. UPGMA cluster analysis of the SSR data between cherry and plum accessions based on Jaccard's coefficient of genetic similarity (1-29 plum and 32-56 cherry).

\section{DISCUSSION}

In this study, we report the genetic characterization of traditional cultivated cherry and plum accessions in East Anatolia with the use SSR markers. The results obtained from the 
present study showed that microsatellites can be effectively used for fingerprinting purposes in Prunus species. While respectively 4 and 19 alleles were detected at the loci UCD-CH13 and UCD-CH17 in North American plums (Rohrer et al., 2004), we found respectively 4 and 10 alleles in the East Anatolian plum accessions and 5 and 10 allelles in the cherry accessions. The numbers of alleles in the plum and cherry accessions were either equal or similar for the UCD$\mathrm{CH} 13$ locus, but they were remarkably lower for UCD-CH17 locus compared to the findings of Rohrer et al. (2004). UCD-CH21 and UCD-CH31 loci were previously used by Rohrer et al. (2004) in the analysis of North American plums, but they were not scored. In the current study, which analyzed 28 cherry accessions, 5 and 10 alleles were scored, respectively. The same loci were also used by Struss et al. (2003) for the SSR-based genetic characterization of 27 cherry accessions; where 4 each alleles were observed. The 4 alleles were detected by the use of the UCD-CH31 locus in this study for the analysis of 31 plum accessions. The number of alleles for the above mentioned 2 loci was remarkably low for the utilization of the cherry and plum gene sources compared to the findings of Rohrer et al. (2004). While 7 alleles were detected at the UDP96-001 locus by Rohrer et al. (2004), the locus produced 9 alleles and 7 alleles, respectively, in the plum and cherry accessions used in our study (Cipriani et al., 1999). The allele number for the PS12A02 locus used in this study for the analysis of the cherry accessions was similar to that found by Downey et al. (2000). In their study on the SSR analysis of cherry (10 alleles), polymorphism was high. However, this locus produced a smaller number of alleles (4 alleles) in the study by Hormaza (2002) on apricot. A genetic similarity of about 95\% between 7 and 10 (24plu007 and 24plu010) in the plum accessions and between 16 and 25 (24che016 and Erz-Macar) in the cherry accessions indicated a possible clonal variational relationship between the accessions. These accessions might have originated from either of the two provinces and might have formed ecotypes through transportation and cultivation, or the genotypes may have a common ancestor.

On the other hand, SSR markers developed from the other Prunus species were successfully used for genetic characterization of plum and cherry cultivars in this study. However, the average numbers of alleles detected in our study in both cherry and plum by these markers were different than those detected in peach and apricot. The Pchgms 1 locus has produced 4 alleles in genetic identifications of both peach (Sosinski et al., 2000) and apricot (Hormaza, 2002), while we found 7 alleles in cherry and 8 alleles in plum. As indicated by the findings of the study, this locus showed a higher number of alleles in both the selected traditional Turkish plum and cherry accessions compared to other Prunus species (peach and apricot). On the other hand, $H_{\mathrm{O}}$ of this locus was identified as being higher than those in all the aforementioned studies. The findings reveal that the region has a rich and sustainable genetic diversity. While the UDP96-010 locus produced 2 alleles and an average heterozygosity of 0.21 in peach (Cipriani et al., 1999), it produced 8 alleles and an average heterozygosity of 0.54 in plums used in our study. The allele number and heterozygosity obtained in plum were found to be remarkably higher compared to the findings of other studies on other Prunus species, which utilized the same locus (Hormaza, 2002; Romero et al., 2003; Sánchez-Pérez et al., 2005). There were 4 alleles identified in the peach sequenced UDP96-019 locus developed by Cipriani et al. (1999), whereas there were 6 alleles identified at this locus in the plum accessions. While 6 alleles were detected in the peach sequenced (Cipriani et al., 1999) UDP96-005 SSR locus in their study on 84 wild cherry genotypes (Schueler et al., 2003), in the current study, the locus produced 6 alleles. There were 11 alleles $\left(H_{\mathrm{O}}=0.516\right)$ detected in the UDAp-404 locus used 
in the current study for the genetic analyses of the plum accessions, and the number of alleles was higher compared to the study by Messina et al. (2004) (who developed this locus) on apricot genotypes (6 alleles, $H_{\mathrm{O}}=0.44$ ). At the same time, an SSR locus (UCDCH13) developed from cherry produced the lowest number of alleles in plum cultivars, while a SSR locus (CPSCT010) developed from plum produced the lowest number of alleles in cherry cultivars in this study. As a result, cross-species transferability of UCDCH13 and CPSCT010 loci does not seem to be completely compatible between cherry and plum cultivars.

The dendrogram based on the selected common SSR loci of the plum and cherry accessions (Figure 3 ) indicated that these cultivars were mainly classified into two groups and that the cherry and plum accessions formed distinct subgroups as expected. The alleles obtained from protected SSR sites were highly similar at the UCD-CH13 locus. The low internal similarity rates of the plum and cherry accessions and the low numbers of synonymous and homonymous accessions indicated a highly protected genetic diversity in the region. Additionally, a remarkably low number of synonymy cases (100\% similarity) indicated that continuous transportation of material is either non-existent or very seldom in the region. No errors were detected, and the findings were verified after a comparison between the morphological denominations of both the plum and cherry accessions and genetic data.

On the other hand, the results of this study on the identification of the East Anatolian plum and cherry gene sources revealed a high potential for rich genetic diversity in this region. This region is of great importance since it has a cold climate and harbors genotypes that comprise a cold tolerant germplasm and since these plum and cherry gene sources evaluated here do not take part in other national germplasms in East Anatolia. Therefore, our findings reported here are important in adding to the international genetic database and identification of cultivar origins, together with the novelty of the use of the selected SSRs.

\section{REFERENCES}

Asma BM (2000). Kayısı Yetiştiriciliği. Evin ofset, Malatya.

Ayanoğlu H (1995). Doğu Akdeniz Bölgesinde Sofralik Erik Seleksiyonu. PhD thesis, Çukurova University.

Ayanoğlu H, Bayazit S, Inan G, Bakir M, et al. (2007). AFLP analysis of genetic diversity in Turkish green plum accessions (Prunus cerasifera L.) adapted to the Mediterranean region. Sci. Hortic. 114: 263-267.

Bowcock AM, Ruiz-Linares A, Tomfohrde J, Minch E, et al. (1994). High resolution of human evolutionary trees with polymorphic microsatellites. Nature 368: 455-457.

Cipriani G, Lot G, Huang WG, Marrazzo MT, et al. (1999). AC/GT and AG/CT microsatellite repeats in peach [Prunus persica (L) Batsch]: isolation, characterization and cross-species amplification in Prunus. Theor. Appl. Genet. 99: $65-72$.

Dirlewanger E, Cosson P, Tavaud M, Aranzana J, et al. (2002). Development of microsatellite markers in peach [Prunus persica (L.) Batsch] and their use in genetic diversity analysis in peach and sweet cherry (Prunus avium L.). Theor. Appl. Genet. 105: 127-138.

Downey SL and Iezzoni AF (2000). Polymorphic DNA markers in black cherry (Prunus serotina) are identified using sequences from sweet cherry, peach and sour cherry. J. Am. Soc. Hort. Sci. 125: 76-80.

FAOSTAT (2008). FAO Statistics Database on the World Wide Web. Available at [http://faostat.fao.org]. Accessed November 2010.

Ganopoulos IV, Kazantzis K, Chatzicharisis I, Karayiannis I, et al. (2011). Genetic diversity, structure and fruit trait associations in Greek sweet cherry cultivars using microsatellite based (SSR/ISSR) and morpho-physiological markers. Euphytica 181: 237-251.

Gerlach HK and Stösser R (1998). Sweet cherry cultivar identification using RAPD-derived DNA fingerprints. Acta Hortic. 468: 63-69.

Granger AR, Clarke GR and Jackson JF (1993). Sweet cherry cultivar identification by leaf isozyme polymorphism. Theor. Appl. Genet. 86: 458-464. 
Gülcan R, Tekintaş FE, Misirli A, Saglam H, et al. (2000). Meyvecilikte Üretim Hedefleri. Türkiye Ziraat Mühendisleri V. Teknik Kongresi, Ankara, 587-615.

Hormaza JI (2002). Molecular characterization and similarity relationships among apricot (Prunus armeniaca L.) genotypes using simple sequence repeats. Theor. Appl. Genet. 104: 321-328.

Lefort F, Lally M, Thompson D and Douglas GC (1998). Morphological traits, microsatellite fingerprinting and genetic relatedness of a stand of elite oaks ( $Q$. robur L.) at Tullynally, Ireland. Silvae Genet. 47: 257-262.

Mariette S, Tavaud M, Arunyawat U, Capdeville G, et al. (2010). Population structure and genetic bottleneck in sweet cherry estimated with SSRs and the gametophytic self-incompatibility locus. BMC Genet. 11: 77.

Messina R, Lain O, Marrazzo MT, Cipriani G, et al. (2004). New set of microsatellite loci isolated in apricot. Mol. Ecol. Notes 4: 432-434.

Minch E, Ruiz-Linares A, Goldstein DB, Feldman M, et al. (1995). Microsat (Version 1.4d): A Computer Program for Calculating Various Statistics on Microsatellite Allele Data. Stanford University, Palo Alto.

Mnejja M, Garcia-Mas J, Howad W and Arús P (2005). Development and transportability across Prunus species of 42 polymorphic almond microsatellites. Mol. Ecol. Notes 5: 531-535.

Onur S (1977). Yerli ve Yabancı Erik Çeşitlerinin Seçimi. Yalova Bahçe Kültürleri Aras. Enst. Derg. 8: 57-64.

Özakman S, Onaz K, Karabiyik N and Ozkarataş I (1993). Erik Çesit Adaptasyon Projesi. Aegan Agricultural Research Instute of the Ministry of Agriculture and Rural Affairs, Izmir. Annual Report for 1993.

Paetkau D, Calvert W, Stirling I and Strobeck C (1995). Microsatellite analysis of population structure in Canadian polar bears. Mol. Ecol. 4: 347-354.

Rohlf FJ (1988). NTSYS-PC Numerical Taxonomy and Multivariate Analysis System, Version 2.0, User's Guide. Exeter Software, Setaouket.

Rohrer JR, Ahmad R, Southwick SM and Potter D (2004). Microsatellite analysis of relationship among North American plums (Prunus sect. Prunocerasus, Rosaceae). Plant. Syst. Evol. 244: 69-75.

Romero C, Pedryc A, Munoz V, Llacer G, et al. (2003). Genetic diversity of different apricot geographical groups determined by SSR markers. Genome 46: 244-252.

Salesses G, Grassely C and Bernhard R (1994). Utilisation des espèces indigènes et exotiques pour l'amélioration des Prunus cultivés, variétés et portegreffe. C. R. Acad. Agric. Fr. 80: 77-88.

Sánchez-Pérez R, Ruiz D, Dicenta F, Egea J, et al. (2005). Application of simple sequence repeat (SSR) markers in apricot breeding: molecular characterization, protection, and genetic relationships. Sci. Hortic. 103: 305-315.

Schueler S, Tusch A, Schuster M and Ziegenhagen B (2003). Characterization of microsatellites in wild and sweet cherry (Prunus avium L.) - markers for individual identification and reproductive processes. Genome 46: 95-102.

Şelli F, Bakir M, Inan G and Aygun H (2007). Simple sequence repeat-based assessment of genetic diversity in "Dimrit" and "Gemre" grapevine accessions from Turkey. Vitis 46: 182-187.

Sneath PHA and Sokal RR (1973). Numerical Taxanomy. Freeman, San Francisco.

Sosinski B, Gannavarapu M, Hager LD, Beck LE, et al. (2000). Characterization of microsatellite markers in peach [Prunus persica (L.) Batsch]. Theor. Appl. Genet. 101: 421-428.

Struss D, Ahmad R and Southwick SM (2003). Analysis of sweet cherry (Prunus avium L.) cultivars using SSR and AFLP markers. J. Am. Soc. Hort. Sci. 128: 904-909.

Wagner HW and Sefc KM (1999). Identity 1.0. Centre for Applied Genetics. University Agricultural Sciences, Vienna.

Wünsch A and Hormaza JI (2002). Molecular characterisation of sweet cherry (Prunus avium L.) genotypes using peach [Prunus persica (L.) Batsch] SSR sequences. Heredity 89: 56-63. 